\title{
Thunderer, Recluse or Apostate? Interruptions and Continuities in the life of a Jacobin Fox
}

Robert Lamb and Corinna Wagner (eds.), Selected Political Writings of John Thelwall (4 vols, London: Pickering and Chatto, 2009), pp. 1056. £350.00 hardback. 9781851969289.

Keywords: Thelwall, political writings, retirement, 'The Champion', lectures, orator

As this special issue of Romanticism demonstrates unequivocally, John Thelwall is attracting a good deal more interest now than he did during the later years of his own life. Publishing aside, since 2006 we have seen his gravestone at Bath conserved, conferences devoted to him there, at York and in Halifax, Nova Scotia, his early play Inkle and Yarico given its world premiere in Memphis, and The Fairy of the Lake, itself never previously performed, treated to a fully costumed airing (with music, songs and dance routines) in Halifax. The performative atmosphere of these gatherings is an indication, perhaps, that there are certain difficulties in assessing the political life of an orator through his writings. The sound, pace, inflection and tone of the spoken words for which Thelwall gained such early notoriety and later acclaim cannot be adequately represented in print, and he intimated as much himself in his published Letter to Henry Cline in 1810. His practice was to speak 'from short notes... which in reality can be intelligible to no-one but myself', from a 'hasty and imperfect outline', and not only was it time-consuming to fill them out for publication, but 'it is in fact, so much more profitable to talk to mankind than to write for them'(iv. 75, 85).

Appraisals of Thelwall's life have themselves sometimes appeared as a 'hasty and imperfect outline', heavily etched in places, overlooked in parts, caricatured in others. Scholarly interest in the mass of relatively accessible materials that document his brief membership of the London Corresponding Society, and his days as an independent political lecturer immediately afterwards, has left the greater part of his career an outline. Thelwall's first biographers, his wife in 1837, then Charles Cestre in 1906, may have confined themselves to the first half of the 1790s, but more recent Thelwall scholars have risen to the challenges presented by the whole life. ${ }^{1}$ And if we are to presume past neglect of Thelwall's later years a judgement of sorts upon his self-proclaimed retirement from politics, we should not be surprised if a new generation of Thelwall scholars re-focus their

Romanticism 16.2 (2010): 207-217

DOI: 10.3366/E1354991X10001078

(C) Edinburgh University Press

www.eupjournals.com/rom 
attention on the period after 1798 and absorb themselves in the search for continuities. In effect, the challenge has been to reinterpret the non-political in political terms.

So, this career-spanning four volume set, published in the Pickering Masters series, is not only an appropriate enough tribute to the man E. P. Thompson judged the most important, 'courageous and judicious' Jacobin agitator active in England during the $1790 \mathrm{~s}^{2}$, but also the most complete and coherent collection of his writings to attract a modern publisher. From the standpoint of the 1790s however, it is not the first, and one or two significant absences in these volumes reflect the editors' intention of supplementing existing material rather than supplying a complete and definitive edition. The present collection is therefore best read alongside Gregory Claeys's The Politics of English Jacobinism: Writings of John Thelwall (Penn State Press, 1995), which stole a march on Robert Lamb and Corinna Wagner by publishing some of Thelwall's most important political writings some fifteen years ago. For this reason, readers will not find included here The Natural and Constitutional Rights of Britons (Thelwall's unused trial defence from 1794), The Rights of Nature (1796) or his Sober Reflections (a comprehensive attack on Burke's Letter to a Noble Lord, also from 1796). The selection from Thelwall's periodical, The Tribune (1795) reprints about a third of the contents of the original three volumes, but none of those already selected by Claeys. A further notable omission is The Peripatetic (1793), another key work but once again, one that has already appeared in a modern critical edition, edited by Judith Thompson.

The fact that neither Thompson's Peripatetic or Claeys's collection is supplanted here is all to the good, for we can now regard both of these as complementary volumes to the present set. Moreover, it has allowed Lamb and Wagner the space and latitude to interpret 'political writings' rather more broadly than Claeys did and to select writings representative of Thelwall's entire career without becoming preoccupied with the brief though significant excitements of the 1790s. Understandably, the centrepiece of this collection remains the Political Lectures (1794) and The Tribune (1795-6), a periodical to which the most substantial volume is entirely devoted. Although, as Lamb and Wagner point out, 'it is truly unfortunate that we can never experience the drama of Thelwall's lecturing rooms' (i. 37); we can, in this substantial collection, savour the energy and vitality of his performance in this period from some of the versions he tidied up for publication. The two Political Lectures of 1794, delivered and published in the year of his arrest for Treason, but rhetorically concerned with the earlier attempts of the arch-Loyalist John Reeves to have him prosecuted for a 'public nuisance', are a perfect example. The tone is set from the very simple expedient of beginning a lecture with the capitalised word, 'CITIZENS', often followed by an exclamation mark. There never was a more important word in Thelwall's vocabulary than this thundering exclamation of commencement and a collectivist statement of democratic recognition. To call these events 'lectures' is partly to miss the point, for they were also panegyric expositions of pure verbal energy:

\footnotetext{
Placemen and pensioners are the priests and confessors of the time, to whose eye alone the volume of political revelation is to be unfolded; and he that has the seditious assumption to expound a single text to the multitude, to teach to the great body of the people the elements of that science in which the happiness and prosperity of the great body of the people are involved, must expect the storms of ministerial vengeance and the thunders of the royal vatican. But shall these intimidate and stop us in the glorious career of truth and virtue? - No citizens! The champions for the rights and happiness of mankind shall vanquish these as they have vanquished former difficulties... (i. 94)

Thelwall's citizens inhabit a Romantic and expressive world of storms, thunders, great
} 
bodies, vanquishings and glories. These 'lectures' are no dry academic exercises in hyperbole, but scripts to be enacted, through the agency of the body, physiognomical expression, dramatic emphasis and careful timing in the Demosthenian manner Thelwall would later teach his students to study and emulate. And if these great effusions live on in their verbal energy, they live too in their frequent knock-about humour.

I remember citizens, when Reeves - the Association Reeves I mean - the busy body fellow there, who has been politically defunct for some time, but whose ghost of late has begun to stalk about the streets, in the semblance of a wild Indian, with 'tomahawk' in his hand, hewing down everything civilised and liberal that comes in his way... (ii. 261) $)^{3}$

The Thelwall we meet in the pages of The Tribune is confident, forthright, unbowed and unfettered. Just as he had seized upon Windham's intended insult, 'acquitted felon', and turned it into a badge of honour so too he dealt with the 'stigma' of Jacobinism; not by denial but by asserting that if those who call for reasoned reform are Jacobins, then Chatham and Chesterfield were as deserving of the epithet as he was. 'When you give to truth and justice an odious name', he told his audience, 'the name ceases to be odious any longer' (ii. 253).

But this is the Thelwall we know best. Undeniably rich and rewarding as The Tribune is, Lamb and Wagner's collection allows us to see it properly surrounded and contextualised by a wide range of unexpected gems, many of which are little known to non-specialists and some of which may not at first glance seem particularly political. The inventive and combative Prospectus of a Course of Lectures on classical history, with which Thelwall audaciously used metaphor to test the strength of the Gagging Acts in 1796, is here and so too is the little known doggerel ballad, John
Gilpin's Ghost, in which he satirised the forces of provincial reaction in 1795 and humorously summarised his own practice in the process: 'He tells them, common folks are men/ And should like men be treated/ Nor like a swinish multitude/ By wealthy knaves be cheated' (i. 103-131).

It is a shame then that, aside from the Ode to Science, the patriotic Trident of Albion of 1810 (an 'epic effusion' on Nelson) and a scattering of examples from The Champion in the 1820s, so little of Thelwall's more overtly political verse has found its way into these four volumes; if not for its quality, which is decidedly uneven, at least for its content. After all, his earliest overtly political excursion into print, an 'Ode on the Destruction of the Bastille', published under his own editorship in the Biographical and Imperial Magazine in 1789, was a poem, and sonnets like 'To Tyranny' and 'The Cell' from 1795, or the more important 'Lines Written in Bridgwater' from 1797 - in which he first announced his political disillusionment - are nothing if not political writings. They are certainly more so than Thelwall's two cantankerous and repetitive refutations of Francis Jeffrey's critique of the Prefatory Memoir and Poems in the Edinburgh Review which together occupy 80 pages of the third volume. One has to search quite diligently for the 'political' in this largely unedifying and bitter personal spat and Thelwall does not emerge from it with any great credit.

Nevertheless, the temporal spread and variety of form on offer in Lamb and Wagner's selections is considerable and the chronological coverage worth emphasising. Thelwall was only 27 when he wrote the earliest piece included here, the Ode to Science in 1791, and just 29 when he joined the London Corresponding Society. His meteoric ascendancy in that organisation caused him to celebrate his $30^{\text {th }}$ birthday in the Tower awaiting trial for High Treason. By the time he was so notoriously hounded out of public life and into rural 
self-sufficiency at Llyswen, he was still a young man in his early 30 s. Standard accounts of his life and influence usually end there, in defeat, exile and harvest failure, neglected by his former friends and supporters and shattered by the sudden death of his six year old daughter. 'The political fox was now dead', as E. P. Thompson so emphatically put it. ${ }^{4}$

The third and fourth volumes in this collection are invaluable and unusual for reminding us that Thelwall's years as a recluse did not place a full stop upon his career; rather, they punctuated it with a hyphen. From his dabblings in picturesque travel writing for the Monthly Magazine in 1797 and various theoretical works on the treatment of speech disorders (c. 1810-14), to his return to political journalism with The Champion in the era of Peterloo and Cato Street, Thelwall's enduring adherence to radical thought beyond the 1790s and over several ensuing decades must now be seen as vital to any understanding of his life. Fittingly then, Lamb and Wagner close their selection with the Morning Chronicle's account of Thelwall's last great public speech, made over the grave of his LCS comrade, Thomas Hardy, in 1832, just two years before his own demise at the age of 69 .

The notion of a 'hyphen' in Thelwall's life during the Llyswen years is worth considering in some depth, now that we have such a catholic selection of his later 'political' writings upon which to draw. As the editors note in their introduction to the Memoir, Thelwall was at pains to use this autobiographical sketch to draw a line between the 'politician' and the man by 'fleshing out his familiar and private self'. Yet his own advice that the former should now be 'forgotten', was not unqualified for he desired readers to know that he remained 'unchanged in his opinions'. The writings represented in volumes three and four of this collection are presented by the editors as works in which 'Thelwall's claim to have withdrawn from active politics and his various efforts to refashion himself' can be assessed against the evidence, for there is plenty here, they suggest, 'that reveals his own reluctance, or inability, to leave politics behind' (iii. 57). This is just as well, given a set of books with the title 'Selected Political Writings', but the remark does highlight the slight awkwardness of a project that identifies as 'political' a series of writings defined by their author as denials of politics. In this, Lamb and Wagner's collection is representative of much recent work by Thelwall scholars for whom the interpretation of radical continuities and reconfigurations has been central. Such reappraisals, many of them from literary scholars rather than social historians, have perhaps been provoked by the offhand dismissals of E. P. Thompson (for whom Thelwall was 'always ambitious to cut a figure in the world of letters') towards the erstwhile orator's walking tour of 1797 ('unremarkable'), his poetry of 1795 and 1801 ('mediocre') and his novel-writing in 1801 ('conventional'). Scathing judgements like these sealed Thompson's disappointment with a radical icon who had promised so much towards the making of class, but who finally succumbed to the greater will of Old Corruption to silence his voice and enforce premature 'retirement'. ${ }^{5}$

Like many Romantic writers of his day, Thelwall did not always talk about retirement as a permanent state. On the contrary, he had used the Tribune to announce his retirement 'for a while' during the summer of 1795, on the grounds that public advocates like himself need 'to retire occasionally from the busy haunts of life to that retirement where lonely, deep and serious meditation may... confirm in him those great truths which, before he can propagate with propriety, he must thoroughly understand'. Temporary immersion in the Natural world, in 'contemplating those beauteous scenes which abound the part of the country I retired to', offered not just respite but refreshment. From this perspective, Thelwall was able even to draw strength from his 
imprisonment in the Tower and 'the charnel house of Newgate', though 'no kindness, it is true, was intended'; indeed it is the central theme of his sonnet, The Cell. Retirement in 1795 would permit him to adjust the balance between passionate oratory and the reason upon which it was built, so that Beaufort Buildings would remain 'a theatre of instruction; not a theatre of mischievous inflammation, and that truth, not irrational heat and pell mell violence may be the consequence of your attending round this Tribune' (ii. 86-7, 164). Although Thelwall clearly intended his later period of retirement as a more lengthy withdrawal, the hyphen remains a more useful metaphor than the full stop.

As has often been noted, Thelwall attributed his retirement at Llyswen to the apparent impunity with which Loyalist mobs, 'sanctioned by magistracy itself', had assaulted his person and broken up his provincial lectures in Norfolk, the Midlands and the North between August 1796 and May 1797. He chronicled in detail some of the worst outrages at Yarmouth (where he survived an attempt to press him into the Navy), Wisbech and King's Lynn in An Appeal to Popular Opinion Against Kidnapping and Murder (i. 133-172), the fullest published version of which closes volume one of the collection. As the Prefatory Memoir later confirmed however, further factors; ill-health, the 'interruption' of family life, official interference with his mail, an inability to meet the expenses of his rented London lecture rooms, and his desertion by 'wearied' friends, also played a part. An added complication, still under-researched, was the Courier affair. While at Derby in 1797, Thelwall 'was applied to by the late principal proprietors of the Courier to undertake the management of that paper, a proposal which he readily accepted'. He was forced out of the job by some undisclosed but evidently influential pressure after only a fortnight, and it was at this point in the Memoir that Thelwall announced, 'Such was the conclusion of his political career' (iii. 78, 80-81). Historians have assumed this to have been a local paper, but no copies of it have survived and the only Derby paper of that name appears to have been ultra-Tory in character and to have been launched no earlier than 1828. The elephant in the room is the somewhat better known London Courier and Evening Gazette however, one of the most reform-minded papers in the country in 1797. The Courier was undergoing some restructuring at this time, and had a close association with Thelwall. It alone carried Thelwall's own account of the attack made upon him at Stockport (written shortly afterwards at Manchester), and gave Thelwall room to write personally and at length about the Norwich riot. It was to the Courier, moreover, that Thelwall addressed his first letter after arrival at Llyswen, putting the record straight about the riot at Ashby. More was intended to follow, for, 'I feel myself called upon to state the facts which, by your leave, I shall do through the medium of your paper, as soon as leisure and circumstances will permit ${ }^{\prime 6}$. Evidently they never did but, while it would admittedly be odd for Thelwall to be on such apparently good terms with the London Courier if he had just been forced out of a position with it, we should perhaps be cautious in making any assumption that it was with a small and unverifiable provincial paper that he had hoped to re-launch his political career. Rumours to that effect were certainly circulating and in June they had come to the notice of the Observer: 'Thelwall has been stated to be the editor of an evening publication, more remarkable for ability than moderation', noted that paper. 'Believing the report designed to injure that property, we willingly accede to the request made to us to contradict it'. If Thelwall had indeed just been offered and then refused the editorship of such an important national newspaper, the importance of the incident in the story of his 
silencing, hitherto misunderstood by historians, now deserves some rigorous investigation. ${ }^{7}$

The determination with which Thelwall set about publicly signalling his Llyswen retirement reveals an extraordinary ability for disassociation. For The Phenomena of the Wye, on which he began work as soon as he arrived in his 'little cottage' at the end of 1797, he transformed himself wholeheartedly into a student of picturesque landscape, preoccupied by the beauty of Autumn and the sublimity of Winter, his identity collapsed into the simple initials, 'JT' (iii. 4-5). Thelwall frequently emphasised the humble simplicity of his new life at Llyswen by prefacing it with the innocent adjective, 'little', as though the very term signalled humility and withdrawal. ${ }^{8} \mathrm{We}$ may indeed trawl for politics in this brief work, and be rewarded by Thelwall's asides about the ease with which the landowning class could assimilate financial hardship caused by winter flooding, and that 'calamities of this kind are, in reality, less to be deplored than the ruin of a cottage, or the destruction of some poor labourer's little crop of leeks and potatoes' (iii. 8). Perhaps to keep his intellect alive in the midst of all this Romantic rusticity, Thelwall also sent occasional 'reflections' (anonymously) to the Monthly Magazine at this time, some of which are reproduced here, on the origins of liberties, the enforced cultivation and settlement of 'wastes', and on the injustices of partial taxation (iii. 9-13). But if these interventions demonstrate political engagement in abstract terms, Thelwall continued to distance himself from specifics. In the more weighty Pedestrian Excursion (iii. 15-55), published in the Monthly Magazine by instalments between 1799 and 1801, Thelwall recalled a walking tour from London to Somerset to visit Coleridge immediately before his retreat to Llyswen in 1797. Here he denigrated 'mongrel squire-farmer(s)' whose monopolies of agricultural land threw cottagers onto the parish and here too he cornered the occasional labourer with whom he hoped to discuss 'political economy'. To his disappointment, they did not share his interest in abstractions and wanted only to talk of the 'temporary politics' of the Naval mutinies at Spithead and the Nore (iii. 23-4).

If the mutinies were so much sound and fury to Thelwall now, readers of these volumes will not fail to notice the irony of the rather different attitude he had taken to crowd attacks on his provincial lectures in An Appeal to Popular Opinion a year earlier, and to his own arrest and imprisonment in The Tribune of 1795 (ii. 93-114). Of course, Thelwall did have cause in 1797 to distinguish a studious and philosophical interest in reform from anything resembling support for popular action. He will have been conscious of the spurious whispering campaigns that were placing him amongst the mutineers as a co-conspirator. The Admiralty lawyer who found an 'inflammatory address to the army inducing them to revolt' amongst papers seized at the Nore, annotated them for Home Office use with advice that it was also 'the subject of one of Mr Thelwall's Lectures'. Elsewhere, the Pittite True Briton alleged that Thelwall was on the Isle of Wight during the mutinies where he was 'not an indifferent spectator $^{\prime 10}$, while on June $9^{\text {th }}$ Isaac Cruikshank planted him below decks as confidante and grog-server to the mutineers in a satirical print, The Delegates in Council. 'Tell them we intend to be masters', Thelwall advises them, 'I'll read them a lecture'. On 29 June Thelwall left London on his Pedestrian Excursion and on the very day that the mutiny's leader, Richard Parker, was hanged.

Consciously or otherwise, Thelwall used his tour and then the brief sojourn with Coleridge and the Wordsworths at Stowey to keep himself out of the limelight, despite the inconvenience of having his footsteps dogged by a Home Office spy. As a result, the loyalist press triumphantly announced Thelwall's retirement to Llyswen at the end of July, by 
which fortuitous timing he also distanced himself from the simultaneous illegal open air public meetings of the Corresponding Societies planned for 31 July in London, Nottingham and Sheffield, and for which his former colleagues Binns, Galloway and Hodgson were all arrested. 'One good effect at least has been produced by the Treason and Sedition Bills, which is that of having driven Mr Thelwall, by his own confession, to "an obscure little village, whither he has retired to cultivate the earth and live by the sweat of his brow, undisturbed by the rumours or the politics of the day"', rejoiced both the Oracle and the True Briton. 'The conversion of a Jacobin to a useful member of society, if true, is one of the most extraordinary circumstances of political history'. ${ }^{11}$

Thelwall will not have enjoyed the celebratory tenor of loyalist war whoops like these, but his next self-invention, as a 'professor' of elocution and a lecturer on oratory was certainly characterised by a concern with respectability and public duty, as well as with the business of earning a professional living. Two of the works included here on elocutionary science, The Letter to Henry Cline and the Vestibule of Eloquence, both published in 1810, reveal something of these concerns. The first concludes by reprinting a communication to the Monthly Magazine in which Thelwall traced the origins of his teaching practice from early experiments in the curing of speech impediments to the teaching of sonorous oratory to 'those ingenuous youths who look upwards to the most eligible situations of both active and public life'. This 'blending together... the profession of the rhetorician with that of the teacher of elocution', would address the decline of (political) oratory in England, and create the conditions from which 'might start forth some new Demosthenes to enlighten and to energise the rising generation'. Students would study history, for 'to be an orator to any effective or beneficent purpose, it is necessary to be an historian', moral philosophy, and poetry for 'the improvement of the energies of impressive diction' (iv. 105-8). Thelwall would have to be careful how he taught them history however, for his former attachment to Jacobin-influenced interpretations of the past were by then well known. ${ }^{12}$ Initially this meant stopping with the Tudors, from a 'desire of not meddling with the more recent periods, till the nature of my undertaking were more popularly understood, beyond the danger of suspicion: for I am well aware how much prejudice has to do in retarding the progress of the most useful establishments', so 'my system interferes not with the parties or the theories of those who are intrusted (sic) to my care' (iv. 110). The Vestibule of Eloquence picks up where the Letter to Henry Cline left off, with an assurance that he now feels 'neither taste nor leisure for political disquisition and not to interfere with the prejudices or opinion of any party has become one of the settled principles of his conduct'. This Thelwall may have felt necessary, because the Vestibule was organised around a hagiographic ode to Horatio Nelson, and he was at pains to assure his readers that such populist patriotism was not an expression of church and king loyalty (oh, the irony!) but a love for English independence and 'an indignant abhorrence of the idea of a foreign yoke' (iv. 116). Back in 1795, Thelwall had used The Tribune to make an impassioned plea for internationalism, pointing out the destructive absurdities of national hubris, refuting the orthodoxies of loyalist francophobia and reminding his readers, 'The fact is, that the man who is, in reality, the enemy of any country, is thereby an enemy to all' (ii. 215). But any kinship he may once have felt to Revolutionary France now lay deeply buried in a familiar characterisation of Napoleonic despotism: 'But see! - the Gaul/ Inebriate with success - and, by the pride/ Of wide-extended frontier, urg'd to grasp/At Universal Sovereignty, - defies/All Elements, and all Examples taught/ Of 
over-weening Arrogance...' (iv. 132). As Michael Scrivener has pointed out, Thelwall's nationalism here is not 'aristocratic and royalist' in tenor but 'traditional' and 'constitutionalist ${ }^{\prime}{ }^{13}$ Nevertheless, the poem's hostility is directed not only towards Bonapartism but to 'the Gaul' himself.

At various junctures after 1797, Thelwall reiterated the litany of self-denial and counted the years since his initial withdrawal. What made his position complicated throughout however, was an accompanying insistence that, far from abandoning his politics he had simply internalised them, subsuming the public within the private and making the public anew. In the Letter to Francis Jeffrey of 1804 he confirmed the 'positive and complete abstinence of seven years from every subject or transaction of a political nature or tendency', but wished it to be understood that it did not make him a different man. 'Have I shifted sides like a common prize-fighter? Have I withdrawn myself from one party only to display my violence for another? Or to excite or keep a live a spirit of division and persecution when the exigencies of the times are crying aloud for an emulous and affectionate unanimity?' (iii. 127). Private constancy and the call for political consensus or 'unanimity' were to become familiar themes in Thelwall's rhetoric. Unfortunately, the present volumes do not cover his public return to the platform in November 1818 when, as newly appointed editor for The Champion, he helped secure the parliamentary candidacy of John Cam Hobhouse for Westminster. But Thelwall marked the occasion of his first public political speech for twenty years with a reminder that his retirement, 'alone and deserted on every side', had been undertaken only 'under the consolation that in the private circles of his friends, he should ever maintain, as he felt he had ever maintained, the integrity of his public principles'. This was as maybe, but in his rush to embrace Hobhouse as a consensual figure who might unite the disparate forces of reform,
Thelwall placed himself in active opposition to the rival candidature of William Cobbett and to Henry Hunt who proposed him. This, in turn, put him at odds both with former comrades from the LCS like John Gale Jones (for whom Thelwall, a.k.a. 'the professor', had become part of a 'junto', conniving to keep 'universal suffrage and annual parliaments... as carefully out of sight and hearing as though they had been entombed in the grave') and the new wave of radical ultras like Watson and Thistlewood. ${ }^{14}$

Given the quantity and relative obscurity of the potential material, the selections from Thelwall's five-year tenure of The Champion are regrettably brief, take up less than twenty pages, and are heavily slanted towards his verse contributions. As the editors explain, Thelwall had always wanted the paper to be seen 'as much a Literary as a Political miscellany' (iv. 175), and the reader will find both in Thelwall's working notes for his unresolved 'national Epic', the Hope of Albion. This work, which preoccupied Thelwall for more than thirty years, exists in print form only in disunited scraps, but its intention was to bring together his political, literary and historical aspirations into an anglo-saxon verse-allegory. 'The consummation of the action is the establishment of the English Constitution on the broad bases of civil and religious Liberty' he explains, 'from whence all the other glories of the united realm, military, naval, commercial and intellectual, are virtually derived' (iv. 192). The mild tenor of Thelwall's broadly reformist political writing for the Champion selections offered here should perhaps be read alongside some of his rather less mild editorials between Peterloo in August 1819 and the execution of the so-called Cato Street conspirators the following Spring. In September, for instance, Thelwall contributed some historical observations on the constitutional duty of resistance to tyranny, equating acquiescence with treason and declaring that, 'Those who adhered to all the arbitrary measures of Charles 
I were rebels to the constitution' ${ }^{15}$ Peterloo itself, he asserted, should not be regarded as a tragedy but a government 'conspiracy', without which 'the future historian may be expected to doubt whether the Cato Street conspiracy would ever have existed ${ }^{\prime}{ }^{16}$ It's a great shame $^{\prime}$ that more of this uncharacteristically outspoken and overtly political material from the Champion years has not found its way into these volumes. This was the period, after all, in which the Jacobin Fox emerged most fully from hiding, rediscovered his political voice, but then lost it again when he found himself arrested and charged with libel by members of the Tory Constitutional Society, and went back to ground in 1821 as speedily as he had re-emerged. Thelwall's relationship with the radical movement in the post-Peterloo years, sketched briefly by Michael Scrivener ${ }^{17}$ but catalogued in some detail in the pages of The Champion, is worthy of greater attention than it receives here. As Scrivener has shown, Thelwall was not wholly unsympathetic to ultra-radicals like Thistlewood, but ultra-radicals did not generally rush to embrace him and some were openly hostile. William Benbow for example, made Thelwall a central figure of ridicule in his Age of Humbug, a work dedicated to the exposure of 'imposture, dupery and quackery', which found the 'professor' an apostate and hypocrite, and his respectable submersion in elocutory science irrelevant to the pressing material needs of the people. ${ }^{18}$

While the tendency of recent scholarship to rediscover the longevity of Thelwall's Jacobinism has been both important and necessary, we should be wary of over-emphasis. Thelwall, the acquitted felon of 1795, may have shown enormous bravery in meeting head-on the draconian anti-liberalism of the Two Acts by continuing to lecture on reform. But he was not unique. Other radical orators withstood loyalist pressure and state repression, endured longer periods of imprisonment and emerged with a less compromised radicalism than
Thelwall. Michael Scrivener has already drawn our attention to the contrasting experience and contributions of Robert Wedderburn and Thomas Spence, for example. Wedderburn, the 'rough and unlettered' son of a Jamaican slave who lived and died in poverty, had little in common with Thelwall in terms of literacy, manners and social class, but he lived over almost exactly the same period (he died a year later, aged 72) and like Thelwall, he was an impassioned orator whose 'words shook the room' ${ }^{19}$ Thelwall is also worth contrasting with John Gale Jones, who had shared the rostrum with Thelwall at Copenhagen House and who embarked upon a radical speaking tour of his own in 1796, continued to play an important political role in London's debating clubs, stood trial for seditious libel while Thelwall was acting the recluse at Llyswen, and served a further year for exercising free speech in 1810 while Thelwall was enjoying his professorial comforts at Lincoln's Inn Fields. Jones was not only 'steady to his principles', according to his obituarist in the Northern Star, but 'a very captivating' speaker, who 'had words at will', so that, exposed to his oratory, 'the ear was tickled by a concentration of sweet sounds'.$^{20}$

Thelwall's political ambivalence, meanwhile, allowed him to impress mainstream newspapers like the Manchester Times as a lecturer whose words were now 'happily chosen and happily placed' and his 'figurative illustrations... inspired by genius' ${ }^{21}$ This was not the sort of accommodation afforded to Wedderburn or Gale Jones and neither was it the sort of review Thelwall had been accustomed to in the 1790s. Thelwall's oratory, in other words, now that we have such a comprehensive guide to it, requires further contextualisation within the radical practice of the period, and his deteriorating reputation within the revived radical reform movement of the post-war years deserves especially close attention.

It is hard to avoid the perhaps frustrating conclusion that however diligently we might 
pan for gold from the writings of Thelwall's post-Llyswen years, and however interesting these writings might be from a holistic point of view, it is his days in the LCS, and The Tribune lectures in particular, that continue to command our attention. Putting aside any reservations about the political value of some of the later writings included in this collection, and stifling any disappointment at the non-inclusion of the political journalism of the 1818-21 years, these four volumes do an immensely impressive job in collating at last much of the first hand evidence for Thelwall's public life. They help us to understand him, for the first time perhaps, not only as the most prominent English Jacobin of the 1790s, but as truly the sum of his parts; propagandist, elocutionist, historian, poet, picturesque traveller, man of letters, and democrat. He is, in turn, inspiring, frustrating and enigmatic, and probably the most significant figure of the period still awaiting a modern biographer. Robert Lamb and Corinna Wagner are to be congratulated for bringing these texts together and for providing helpful annotations. They have not, however, been well served by their publishers whose typesetters have left too many textual errors uncorrected. Thus (iv. 118) we are treated to 'Geebleness and Dissonance of Voicel', 'disvoveries', 'reginements' and 'ecnocuntered', on a single page of, ironically enough, The Vestibule of Eloquence! We may thank Pickering and Chatto for publishing these volume, but in a set of books priced at $£ 350$ the carelessness of the production is much to be regretted.

Steve Poole

University of the West of England, Bristol

\section{Notes}

1. H. C. Thelwall, The Life of John Thelwall, vol. 1 (London, 1837); Charles Cestre, John Thelwall: a Pioneer of Democracy and Social Reform in England During the French Revolution (London, 1906). The most thorough modern assessment of
Thelwall's life to date is Michael Scrivener's absorbing, Seditious Allegories: John Thelwall and Jacobin Writing (University Park Pennsylvania, 2001). For the biographical prospect before us, see particularly Nicholas Roe, 'The lives of John Thelwall: another view of the Jacobin Fox' in John Thelwall: Radical Romantic and Acquitted Felon, ed. Steve Poole (London, 2009), 13-25.

2. E. P. Thompson, The Making of the English Working Class (London, 1968), 172-3.

3. Thelwall's allusion to Reeves as a 'wild indian' with a tomahawk is a topical and satirical reference to the fiercely loyalist but short-lived daily newspaper, The Tomahawk or Censor General, which consistently urged further state prosecutions since 'the MISCREANT Thelwall and his daring associates have become lost to all respect for the laws of their country'. The first edition, which had appeared a week before this speech was made, attacked Thelwall in a verse which began, 'Poor Mister Thelwall has exhausted/ All his little stock of wit'. Perhaps not. By mid November, other papers, including the Morning Herald had begun referring to 'Tomahawk Reeves', and following Thelwall's threat of legal action for calling him a 'miscreant' the Tomahawk began using the term every time it referred to him. See Tomahawk, 27 and 31 October, 21 November 1795.

4. E. P. Thompson, 'Hunting the Jacobin Fox', Past and Present, 142 (1994), 128.

5. See my 'The Character and Reputation of an Acquitted Felon' in Poole, Radical Romantic and Acquitted Felon, 9-11.

6. The Courier (5 January 1798).

7. The Observer (25 June 1797).

8. For example, 'While I was cultivating my little farm in Wales...', from the Letter to Henry Cline of 1810 (iv. 88).

9. See Roger Wells, Insurrection: The British Experience, 1795-1803 (Gloucester, 1986), 104.

10. True Briton (12 May 1797).

11. Oracle (20 January 1798) and True Briton (20 January 1798).

12. See my "Not precedents to be followed but examples to be weighed": John Thelwall and the Jacobin sense of the past' in Poole, Radical Romantic and Acquitted Felon, 161-175.

13. Scrivener, Seditious Allegories, 192.

14. Morning Chronicle (18 November 1818); Thelwall revisited his 20 year abstinence several times as 
opportunities presented themselves during the subsequent campaign. See for example The Champion (17 January 1819). See also Morning Chronicle (3 September 1819), and Western Flying Post (9 September 1819). For the drawing of battle lines between Hobhouse, Burdett and Thelwall on the compromising side, and Cobbett, Hunt, Jones and Watson on the universal suffragist side, see also Thelwall's pronouncement, 'I have no kind of connection with the partisans of Mr Cobbett', Morning Chronicle (20 November 1819), and the detailed expositions in The Champion (14 February 1819).

15. The Champion (5 September 1819).
16. The Champion (16 December 1820).

17. Scrivener, Seditious Allegories, 197-202.

18. William Benbow, The Age of Humbug (1825). No copies of this periodical have been traced, but a coloured engraving frontispiece is preserved in the British Museum.

19. The Horrors of Slavery and other Writings by Robert Wedderburn, ed. Iain McCalman (Edinburgh 1991), 5, 127; for an excellent analysis of Spence and Wedderburn's writing see Scrivener, Seditious Allegories, 130-166.

20. Northern Star (17 March 1838).

21. Manchester Times (26 December 1820). 